implausible, given current politics, $1.5^{\circ} \mathrm{C}$ is very nearly inconceivable.

Nevertheless, countries calling for more aggressive action - often those that have contributed the least to the problem and now have the most to lose - pushed for the $1.5^{\circ} \mathrm{C}$ IPCC assessment. The deadlines are tight: scientists around the world now have roughly a year to run their models and submit papers to bolster the scarce body of literature surrounding the 1.5-degree goal. The IPCC will present its assessment in 2018, just before UN negotiators hold their first major meeting to assess progress under the Paris agreement and presumably to discuss ways to hasten action.

At a meeting in Oxford, UK, last week, researchers discussed the 1.5-degree agenda. There is plenty of work to be done. On the impacts side, for instance, scientists are planning to explore the probable increase in extreme weather using new tools to analyse global warming's contribution to major storms and droughts that are already occurring. Further analysis will help to define how much those risks will increase as the world moves from $1.5^{\circ} \mathrm{C}$ to $2^{\circ} \mathrm{C}$ of warming. More generally, we need information about the progression of impacts on everything from coastlines and forests to human health, food and water supplies.

The mitigation agenda is more difficult. Scientists can and will run the numbers and chart theoretical pathways to $1.5^{\circ} \mathrm{C}$ of warming, just as they have for $2^{\circ} \mathrm{C}$. But after more than quarter of a century of delay, there are no easy answers. Hitting either of these targets would require some extreme measures, such as wholesale abandonment of valuable fossil-fuel infrastructure or development of industrial-scale bioenergy systems that also pull carbon dioxide out of the atmosphere and sequester it underground, resulting in negative emissions. So daunting are the numbers that some researchers point to the emergency backstop of geoengineering, including strategies such as pumping aerosols into the atmosphere to block sunlight.

Unless the politics swirling around energy and climate policy change dramatically, the targets are clearly out of reach, but that does not mean

that the IPCC's latest research exercise is a waste of time. Regardless of any particular political target, the work can shed light on what deep decarbonization might mean for both human societies and the natural environment. That is information that policymakers - particularly those pushing for aggressive action - can use. Each solution comes with its own challenges: technical, ethical, social and political. Ecologists and agronomists, for instance, need to explore the implications for

"After more than quarter of $a$ century of delay, there are no easy answers." land use and food production if bioenergy is scaled up with carbon-capture technologies. Social scientists need to engage on issues of equity, keeping in mind the parallel global goals of promoting sustainable development and eradicating extreme poverty across the planet. And governments have not exhausted their policy options. Political scientists and economists must continue to look for creative ways to break logjams at the national and international levels.

One option, discussed at the International Conference on Fossil Fuel Supply and Climate Policy this week, also in Oxford, focuses on restricting the supply of fossil fuels coming onto the market. This wouldn't staunch their use much unless all governments participated - which is hard to imagine - but in theory it could help to drive up the price of oil, gas and even coal, making renewable energies a bit more competitive. And if governments can determine what is taken out of the ground, could they also mandate what goes back in, requiring companies to bury emissions if they are to continue producing fossil fuels?

As it stands, there is minimal evidence that humanity will commit to its maximum climate ambition, but that could change as the impacts of global warming come into better focus. New technologies could also make it easier - and cheaper — to increase commitments. Scientists can help to provide a better basis for aggressive action when and if that happens.

\section{Twenty years on}

\section{The Habitat III meeting faces greater challenges in urban planning than its predecessors.}

$\mathrm{I}$ n August 1932, the streets of Quito witnessed one of the world's briefest and least-known conflicts. Supporters and opponents of president-elect Neptalí Bonifaz Ascázubi fought what has been dubbed the Four Days War. As with much civil strife, historians blame the fighting on trigger events elsewhere. Shockwaves from the Wall Street crash three years beforehand had set the people of Ecuador on an economic collision course that determined their future.

The streets of Quito will see a different kind of four-day event next month, but the implications for the country and the wider world could be just as decisive. From 17 to 20 October, experts in sustainable development, planning and urban science will gather for the third United Nations Conference on Housing and Sustainable Urban Development.

Yes, the third. Habitat III, as the meeting is known, comes after two little-remembered (beyond the specialist community) prequels - in 1976 and 1996. Which means that countless millions of city dwellers have been born since Habitat II closed its doors two decades ago.

The challenge for the next twenty years is a familiar one: more people chasing fewer resources. But the problems are especially acute when viewed through an urban lens. Transport, pollution, natural hazards, climate change, physical and mental health, clean water - and all affecting billions of inhabitants of the urban sprawl in a way that would have been hard to imagine when the meeting series was set in motion back in 1976. In hindsight, a few days of discussions every twenty years was never likely to be sufficient to sort that lot out.
Nature has increased its focus on cities and urban science in recent years, to acknowledge both the issue's rising profile and the concomitant surge in academic research. This week, in a series of Comment articles, we explore some of the items on the Habitat III agenda.

Joern Birkmann and colleagues (page 605) draw attention to the needs of small and mid-sized cities, especially in Asia and Africa, and argue that these deserve higher priority than some of the giant urban centres that tend to monopolize attention and resources. Smaller cities are more vulnerable to problems such as extreme weather, they say.

Richard Forman and Jianguo Wu ponder where to put the next billion people expected on the planet by 2030 (page 608) and make the case that more planners should do the same. And Michele Acuto (page 611) points out that cities and civic leaders need to forge better political and strategic links to policymakers. "The promise of cities is hampered by patchy collaboration with national governments, limited access to global governance processes such as the sustainable development goals and Habitat III, meagre funding for collaboration, and poor data collection and sharing," he writes. Finally, the Books and Arts pages (page 614) highlight works that probe the relationship between cities and their people.

The Quito meeting is expected to issue a declaration of intent, which will not be legally binding but should help to set new global standards for sustainable urban development and then guide the ongoing process. Scientists and funders have a key role here, by building on the promising start to fully develop the concept and the promise of urban research.

Quito lies close to the Equator, but most people there call the line of zero latitude la mitad del mundo to avoid confusion. (Ecuador is Spanish for Equator.) It means 'middle of the world'. But for four days that must speak for twenty years, Quito is not just at the middle. It is the centre. 